\title{
Mapping the Routes: An exploration of charges of racism made against the 1970s UK Reclaim the Night marches
}

This article addresses early charges of racism, made against the original UK Reclaim the Night (RTN) marches in the 1970s. These charges appear to have stuck, and been accepted almost as a truism ever since, being maintained in several academic texts. Using archive materials, and recent, empirical qualitative research with founding RTN activists and participants, I shall investigate the emergence of RTN in the UK in 1977 and the practicalities and influences behind this type of protest. I will also consider possible reasons behind the charges of racism, addressing justifiable critiques and concerns. I will conclude that the specific charges made against the first RTN marches were inaccurate. However, I will also explore possible reasons why concerns about racism surrounded these marches at their formation.

\section{Introduction}

In this article I shall trace the emergence of the Reclaim the Night (RTN) march in the UK in 1977 and explore charges of racism made against the protest soon after its founding; which have been frequently repeated since. RTN is traditionally a women-only, night time, urban protest march against all forms of male violence against women. Specifically, the charges made against the original marches are that they: purposely and unthinkingly chose routes through urban areas with a high proportion of Black and Minority Ethnic (BME) communities; demanded increased policing; and made links between Black men and the crime of rape. To investigate these charges, I will explore evidence from 
This is an author pre-print of an article published in Women's Studies International Forum. The definitive publisher-authenticated version Mackay Finn (2014) 'Mapping The Routes: An exploration of charges of racism made against 1970s UK Reclaim the Night marches', Women's Studies International Forum, 44, pp. 46-54 is available online at: http://www.sciencedirect.com/science/article/pii/S0277539514000521

original periodicals of the 1970s UK Women's Liberation Movement, in which some practical and political decisions behind the first RTN marches are outlined. I will conclude that none of the first RTN marches called for increased policing, nor did any focus on BME communities. However, some commentators have clearly perceived RTN as racist; and there are numerous valid reasons why they may have done so, which I will explore in this article.

This historical investigation and contemporary reflection on the birth of RTN is important, not least because RTN is not just a piece of history, consigned to the shelves of the feminist archives, but is in fact enjoying a global resurgence as a key element of the current feminist uprising observed in the West and beyond (Long, 2012; Budgeon, 2011; Dean, 2010). After regular marches from the late 1970s through to the early 1990s, the RTN protest then appears to have gone into decline, being revived again in 2004 most prominently by the London Feminist Network. Since 2004 the marches have grown from two marches to around twenty such protests every year, across the UK from North to South. This study of the original RTN is therefore arguably timely, and relevant to contemporary feminist activists, scholars of feminist history and of new social movements. In addition, nearly forty years later, questions of exclusion still surround the modern RTN movement. Today this criticism in activist circles more often focusses on issues around the exclusion of men, of trans identified people, and of Queer or non-gender identified people; although the underrepresentation of Women of Colour is still an ongoing concern (Antubam, 2013; Kendall, 2013; G, 2012; Jeffreys, 2012; Kaveney, 2012).

Important debates are unfolding in the current UK movement around the definition and utility of women-only space on RTN marches, the decline of women-only political 
This is an author pre-print of an article published in Women's Studies International Forum. The definitive publisher-authenticated version Mackay Finn (2014) 'Mapping The Routes: An exploration of charges of racism made against 1970s UK Reclaim the Night marches', Women's Studies International Forum, 44, pp. 46-54 is available online at: http://www.sciencedirect.com/science/article/pii/S0277539514000521

organising, the role of men, the role of the police in stewarding marches and the efforts of RTN activist organisers to welcome a diversity of participants. Perhaps as a result of such concerns, the majority of UK RTN marches today are mixed and open to all, including men, in stark contrast to the protest of the past. While debates around these issues are taking place publicly both inside and outside the feminist movement, online and offline, the roots of RTN are harder to map, mainly slumbering in the embrace of the various newsletters, periodicals and magazines through which news and controversy was broadcast throughout the movement pre-internet. Unearthing these roots will shed some light on the beginnings of one of the most well-known and widespread global tactics of feminist protest, allowing this history to perhaps inform the debates today as well as provide a context to scholarly observations of the current UK feminist movement.

\section{The study}

The empirical data in this article is taken from my doctoral field work, carried out in the UK Women's Liberation Movement between October 2011 and January 2012. The critical analysis of my thesis concerned changes in the form and function of this movement over three decades, using the past and present RTN march as a lens and route into this broad consideration. I conducted twenty five semi-structured, in-depth interviews, alongside an activist survey and archival research. Research participants were aged from their late teens to their sixties, they resided all over the UK and reported being active feminists from between one to over thirty years. They had a variety of ethnic, political and sexual identifications. 
This is an author pre-print of an article published in Women's Studies International Forum. The definitive publisher-authenticated version Mackay Finn (2014) 'Mapping The Routes: An exploration of charges of racism made against 1970s UK Reclaim the Night marches', Women's Studies International Forum, 44, pp. 46-54 is available online at: http://www.sciencedirect.com/science/article/pii/S0277539514000521

All research participants have been given pseudonyms, apart from two, from whom I received consent to use their real names. These two participants, both identifying as Radical Feminists, Al Garthwaite and Sandra McNeill, are founders of original 1977 RTN marches in Leeds in the North of England and London in the South of England respectively. Garthwaite is a media consultant and community activist and McNeill is a policy expert on gender based violence with a long history in local government; both are still committed feminist activists. As there is scarce published history on this protest in the UK, I felt it was important to credit these activists for the work they did, for their contribution to the UK Women's Liberation Movement and their foundational role in establishing RTN in the UK.

I too have a history of involvement with RTN, albeit a more recent past. I founded the London Feminist Network and the revived London Reclaim the Night in 2004 and have been active in the feminist movement in the UK for over twenty years. I too identify as a Radical Feminist, and, in order to situate my positionality in relationship to the topic under study in this article, I should also state that I am White and identify my nationality as Scottish. I conducted my research in the UK feminist movement as an insider researcher, though I prefer to refer to my positionality as that of a 'besider researcher'. I use this term because I conducted my research alongside, or beside individuals who I consider to be fellow feminists and activists (Gangoli, 2007; Roseneil, 1995). However, for the duration of my research I stepped back from many practical, activist tasks in order to focus on the field work and thus moved temporarily to the sidelines of a movement I was very much a part of. I felt that this besider position enabled me to broaden, and thus hopefully enlighten and clarify a fuller view of the field under study.

\section{The Roots of Reclaim the Night}


In order to set this article in context I will firstly provide a brief background to the emergence of RTN globally and then focus on its founding in the UK. The roots of the protest appear to be European, early references can be traced back to Brussels in March 1976, to an international conference on male violence against women. Attendees at the International Tribunal on Crimes Against Women held a march on the evening of the last day of the conference to protest against all forms of violence against women (Russel and van de Ven, 1976). This appears to be the first documented incidence of an organised, urban, women's night-time march against male violence against women (TBTN, 2010). While it is likely not the first such event, as women's resistance to male violence against women is presumably as old as this violence itself (Hester, 1992; Lerner, 1986; Hanmer, 1981), in the chronology of the emergence of organised RTN marches, this occurrence in Brussels appears significant.

Women delegates at the conference in Brussels in 1976 took news of the women's night-time protest march back to their own countries and a similar march was held by women in Rome, only a few months later, following a rise in reported rapes in the city (Chan, 2004; TBTN, 2010). The following year, in March 1977, women in Berlin organised a march in response to the rape and murder by a man of a young woman resident in the city. Germany then became host to the world's first synchronised night-time RTN marches, being held across several towns and cities on the same night. That night was the $30^{\text {th }}$ April 1977, and on that date at midnight women marched with flaming torches through towns and cities across West Germany, protesting against sexual harassment and male sexual violence against women (SR 61, 1977). 
This is an author pre-print of an article published in Women's Studies International Forum. The definitive publisher-authenticated version Mackay Finn (2014) 'Mapping The Routes: An exploration of charges of racism made against 1970s UK Reclaim the Night marches', Women's Studies International Forum, 44, pp. 46-54 is available online at: http://www.sciencedirect.com/science/article/pii/S0277539514000521

The synchronised marches in West Germany were covered in the periodicals of the German New Women's Movement, the Women's Liberation Movement of Germany; a magazine called 'Courage' recorded the marches (Erickson, 2010). This coverage was then picked up by journalists working at the UK feminist magazine 'Spare Rib'. Founded in July 1972 , this is arguably one of the most well known of the many and varied newsletters and magazines of the British Women's Liberation Movement of the 70 s and 80 s; continuing to run until 1993 (Bouchier, 1983). Perhaps reflecting the resurgence of feminism mentioned in the introduction to this article, the magazine made a comeback in 2013, with a different name, 'Feminist Times', under the steerage of a member of the original magazine collective (Cochrane, 2013). Returning to the historical context however, in the August 1977 issue of 'Spare Rib', a small article, edited from 'Courage', relays news of the coordinated German marches. Included is a photo of women carrying flaming torches, with their faces painted with women's symbols, alongside the headline "Germany: Reclaiming the Night" (SR, 61, 1977:21). This was the first seed which led to the growth of RTN in the UK, and the phenomenon marched onto these shores later that same year in November 1977.

The news of this new type of protest proved inspiring for feminist activists in the UK. RTN marches were discussed in Scotland at an Edinburgh conference on Revolutionary Feminism, held in July 1977, where activist Sandra McNeill, then based in London, suggested similar protests be held in the UK (McNeill Interview, 21/01/12 ${ }^{1}$ ). Feminists from Leeds were among those present at the Edinburgh conference, and they brought news of the suggestion for UK RTN marches with them back to the groups they were part of in Yorkshire in the North of England. These groups were: the 'WIRES' collective and the Chapeltown Women's Liberation Group (Rees, 2007). Chapeltown is a small residential

\footnotetext{
${ }^{1}$ McNeill reported that Edinburgh activists actually took the idea forward shortly after the conference, and held an RTN march in The Meadows, a large area of parkland in the South of the city. This would therefore be the first ever RTN march in the UK, though I was unable to find documentation on this event or confirm the date.
} 
This is an author pre-print of an article published in Women's Studies International Forum. The definitive publisher-authenticated version Mackay Finn (2014) 'Mapping The Routes: An exploration of charges of racism made against 1970s UK Reclaim the Night marches', Women's Studies International Forum, 44, pp. 46-54 is available online at: http://www.sciencedirect.com/science/article/pii/S0277539514000521

suburb in the North of Leeds, a few miles from the city centre. 'WIRES' refers to the 'Women's Information Referral and Enquiry Service', which was the national newsletter of the British Women's Liberation Movement, published from 1975 to 1985.

'WIRES' was in fact the brainchild of Leeds feminists in the Chapeltown Women's Liberation Group who suggested the need for a national newsletter at the 1975 UK Women's Liberation Movement National Conference. The suggestion was approved and Leeds was home to 'WIRES' for its first forty five issues, before women in York took over production from January 1978. It was in 'WIRES' that the idea of holding co-ordinated UK RTN marches was first aired publically to the national movement in July 1977. In order to explore the charges of racism made against the original RTN, it is necessary to look back through archival material such as 'WIRES', to unearth some of the motivations behind the emergence of this form of protest in the UK. The next section investigates this history, and uncovers the original two advertised themes behind the first RTN. These two themes were: fight rape; and: every woman has the right to walk alone at night without fear.

\section{Mobilisation and mobilising factors}

The early RTN marches in Rome and Berlin were partly mobilised against the crime of rape, and this particular form of male violence against women also emerges as a mobilising factor for the founding of RTN in the UK in November 1977. Prior to this date, rape had been a formal discussion topic at the Women's Liberation Movement National Conference in April 1977, held in Islington, London. (Wheelwright, 1977). Following this focus at the National Conference, several women's groups set up discussion and action 
This is an author pre-print of an article published in Women's Studies International Forum. The definitive publisher-authenticated version Mackay Finn (2014) 'Mapping The Routes: An exploration of charges of racism made against 1970s UK Reclaim the Night marches', Women's Studies International Forum, 44, pp. 46-54 is available online at: http://www.sciencedirect.com/science/article/pii/S0277539514000521

groups on rape, in London in the South, Manchester in the North, Nottingham in the Midlands and Bristol in the South West of England for example (WIRES 36, July 1977).

Rape and all other forms of male violence against women had also been frequently discussed in 'Spare Rib' and other similar periodicals throughout the 1970s however, prior to the emergence of RTN. Not least, due to the crimes of Peter Sutcliffe, dubbed the 'Yorkshire Ripper' by the national press, who murdered thirteen women between 1975 and 1980, several in Leeds, casting a long shadow across the North of England and beyond (Holloway, 1984). In interview, Emmeline for example, a retired teacher, recounted the impact of these murders on the daily life of women in Leeds at the time:

“There was the 'Ripper' stuff going on, I remember driving home through Leeds and seeing women waiting at bus stops and just picking them up and taking her home, even if it was way out of our way, 'cos we were told [by police], you know, stay at home or get a taxi. So, this really politicised women at the time" (Emmeline).

Megan, a university lecturer from Sunderland also recalled a sense of anger at the unsatisfactory police response, experienced by many women as the imposition of a curfew:

"I remember at the time the Yorkshire Ripper. And all these warnings were issued about what women should do to keep themselves safe and it almost amounted to a curfew. I remember sitting in a pub with my extremely politically aware male colleagues. I remember saying, this is really weird, it's really bizarre and if there's temporary measures to bring in, then why not do it the other way round, and until the 
This is an author pre-print of an article published in Women's Studies International Forum. The definitive publisher-authenticated version Mackay Finn (2014) 'Mapping The Routes: An exploration of charges of racism made against 1970s UK Reclaim the Night marches', Women's Studies International Forum, 44, pp. 46-54 is available online at: http://www.sciencedirect.com/science/article/pii/S0277539514000521

Ripper is caught, why don't men not go out, unless they're accompanied by a woman. And they were laughing at me" (Megan).

Against this background of heightened awareness around male violence, Brownmiller's influential history of rape, Against Our Will was published in the UK in 1976, the same year the first Rape Crisis Centre in the UK was founded in London (LRCC, 1984). Perhaps not insignificantly, in the previous year of 1975 , feminists were shocked and angered by the controversial Morgan ruling. This ruling established a defence to rape of 'honest' belief in consent, focussing legal attention on the internal, mental motivations of the accused, and whether they 'honestly' believed their victim had consented, no matter how unreasonable that belief may seem (Bourke, 2007: LRCC, 1984). This defence was eventually expunged with the 2003 Sexual Offences Act, which focusses instead on a reasonable belief in consent, as well as the context in which it is negotiated or otherwise, including whether the alleged victim was inebriated, unconscious or asleep at the time of the offence.

Feminists were also shocked by another legal case, as the general public appeared to be also, when a young soldier called Tom Holdsworth won his appeal in June 1977 against a conviction for a serious sexual assault, which had left his victim with severe internal injuries (SR 61, 1977). The three male judges at the appeal hearing had suggested the victim could have avoided these injuries if only she had 'accepted his advances' (ibid). The judges reduced Holdsworth's initial three year custodial, to a six month suspended sentence, on the grounds of his promising army career. The appeal verdict caused outrage in much of the national press in the UK, and sent shockwaves throughout the Women's Liberation Movement (Brown et al, 2010; Bourke, 2007; Bouchier, 1983). In interview, 
This is an author pre-print of an article published in Women's Studies International Forum. The definitive publisher-authenticated version Mackay Finn (2014) 'Mapping The Routes: An exploration of charges of racism made against 1970s UK Reclaim the Night marches', Women's Studies International Forum, 44, pp. 46-54 is available online at: http://www.sciencedirect.com/science/article/pii/S0277539514000521

Sophie, a sixty two year old bookseller, reflected on her memories of attending the first RTN in Manchester in the North of England. She emphasised the Holdsworth case as a motivator to RTN activism in the region; and also noted the inspiration of Brownmiller's publication the previous year:

"I think it pushed the whole issue of sexual violence against women up the agenda fairly dramatically. The Holdsworth case kind of crystalised it. I mean, we'd just had Brownmiller's book out too. That was all part of the mix" (Sophie).

Feminist groups protested the outcome of Holdsworth's appeal by daubing graffiti on the street outside the Court of Appeal in central London; and on military monuments along The Mall also in central London. Elsewhere, the Manchester Rape Action Group in the North of England painted slogans on local army careers offices and court buildings for example (SR 61, 1977; SR 62, 1977). It was in fact following an article on the Holdsworth case, written by the Bristol Anti-Rape Group, that the idea for a synchronised UK RTN was first raised, in issue 36 of 'WIRES'. Referencing the West German marches, the small suggestion was made by "the WIRES Collective" as follows:

Women in West Germany demonstrated for the right to walk unafraid and unhassled on the streets at night (See Spare Rib 61)...Women in Britain are afraid to walk home at night, especially with the all the recent rape reports fresh in our minds. Couldn't we organise similar national demonstration,,.to help turn our fear into anger and action (sic) (WIRES 36, July, 1977:16). 
This is an author pre-print of an article published in Women's Studies International Forum. The definitive publisher-authenticated version Mackay Finn (2014) 'Mapping The Routes: An exploration of charges of racism made against 1970s UK Reclaim the Night marches', Women's Studies International Forum, 44, pp. 46-54 is available online at: http://www.sciencedirect.com/science/article/pii/S0277539514000521

This suggestion was then taken forward in 'WIRES' and the organising and planning of the marches seems to have been taken on by women in a group called the Leeds Revolutionary Feminist Group. Apparently however, women of a variety of feminist identities were involved in the organisation of the first Leeds RTN and the organising group also sometimes referred to themselves in articles and letters simply as the: 'Leeds Reclaim the Night Group' (McNeill Interview 21/01/12). Revolutionary Feminism itself is a uniquely British school of feminism, founded by Sheila Jeffreys at the UK Women's Liberation Movement National Conference in London in April 1977 (SR 58, 1977). It is in this school of feminism that the UK RTN is firmly rooted, at least in terms of its initial emergence, as it was the Leeds Revolutionary Feminist Group who made the first official, public call for coordinated UK RTN marches, announcing in issue 38 of ' WIRES', published on the $24^{\text {th }}$ September 1977:

Torchlit demonstration: The Leeds Revolutionary Feminist Group wants to hold a womenonly midnight demonstration on the theme of 'every woman has the right to walk alone at night without fear' and 'fight rape'. We want to hold ours in the Chapeltown area of Leeds where a Jack the Ripper type character has murdered several women over the past two years, and to get as many women as possible on the march. We thought it would attract a lot more publicity and have more effect if women in as many different towns as possible all over Britain could demonstrate on the same night, which we have fixed for NOVEMBER $12^{\text {th }}$. (sic) (WIRES 38 , September 1977).

After receiving a positive response to this advert, the organising group called on women organising regional RTN marches around the UK to inform them in Leeds so that 
This is an author pre-print of an article published in Women's Studies International Forum. The definitive publisher-authenticated version Mackay Finn (2014) 'Mapping The Routes: An exploration of charges of racism made against 1970s UK Reclaim the Night marches', Women's Studies International Forum, 44, pp. 46-54 is available online at: http://www.sciencedirect.com/science/article/pii/S0277539514000521

they could produce an accurate national press release. The marches were advertised in issue 40 of ' WIRES' and the date was set for the $12^{\text {th }}$ November 1977. RTN was also advertised in the events listings in 'Spare Rib', in issue 64:

12 November. Torchlit women only midnight demonstration in the Chapeltown area of Leeds, organised by the local Revolutionary Feminist Group on the themes every woman has the right to walk alone at night without fear, and fight rape. They hope women in other towns will do the same on that night in order to attract publicity (SR 64, 1977:24).

On the night itself over twelve English cities took part in the synchronised protest, including: York, Bristol, Brighton, Newcastle, Bradford, Manchester, Lancaster, London and of course Leeds (Toynbee, 1977). The front cover of the January 1978 issue of 'Spare Rib' is covered with photos of regional RTN marches, complete with banners and flaming torches and the magazine contains accounts of up to four hundred women marching on their city centres (SR 66, 1978). The marches were widely proclaimed as a huge success. However, shortly after its founding, accusations of racism were made against RTN; accusations which I shall now explore.

\section{Mapping the routes of RTN}

It is reported in a letter from the Leeds RTN Group to 'WIRES' in March 1978, that accusations of racism were first raised about RTN, to their knowledge, by women at a Socialist Feminist Conference in Manchester in January 1978 (WIRES 47, 1978). The letter recounted that unnamed women had suggested that one RTN march: "unthinkingly went 
This is an author pre-print of an article published in Women's Studies International Forum. The definitive publisher-authenticated version Mackay Finn (2014) 'Mapping The Routes: An exploration of charges of racism made against 1970s UK Reclaim the Night marches', Women's Studies International Forum, 44, pp. 46-54 is available online at: http://www.sciencedirect.com/science/article/pii/S0277539514000521

through a black area" (ibid). The Leeds RTN Group assumed that this criticism was aimed at them as one of their starting points for the Leeds RTN was the area of Chapeltown in North Leeds, which was, and still is a multi-ethnic area with a high number of BME residents (ibid). Garthwaite explained to me in interview (20/01/12) that two starting points were actually used for the first Leeds RTN however, Chapeltown and Hyde Park. The latter was and still is a popular student residential area, predominantly White, in the North of the city and close to the University of Leeds. At the time it was an area unfortunately affected by high crime rates including muggings and assaults, particularly in a large piece of parkland called Woodhouse Moor.

"We decided to have two marches in Leeds, one setting off from Chapeltown community centre and one setting off from Hyde Park going across Woodhouse Moor, because there was lots of harassment and rapes and attacks on students around Woodhouse Moor, it was a notorious place" (Al Garthwaite).

The two marches, of around thirty women meeting in Chapeltown and a further eighty five women starting at Hyde Park, converged to march together into a pedestrianised square called City Square in Leeds city centre. Several members of the RTN organising group actually lived in the Chapeltown area, and, as mentioned, had been part of the Chapeltown Women's Liberation Group, who had founded 'WIRES'. Chapeltown in North Leeds during the mid-1970s was an area that was therefore home to many feminist activists at this time, including many women involved with the organisation of the first RTN, as well as the production of 'WIRES'. Therefore, it seemed practical to them to organise where they lived; as Garthwaite explained in interview: 
This is an author pre-print of an article published in Women's Studies International Forum. The definitive publisher-authenticated version Mackay Finn (2014) 'Mapping The Routes: An exploration of charges of racism made against 1970s UK Reclaim the Night marches', Women's Studies International Forum, 44, pp. 46-54 is available online at: http://www.sciencedirect.com/science/article/pii/S0277539514000521

"locations were chosen because that was probably the two biggest concentrations of active feminists in the area. We didn't choose it [Chapeltown] because it was a Black area. We chose it because we lived there; we all lived there, and you organise where you live." (Al Garthwaite).

In their letter to 'WIRES' the RTN organisers refuted the charge of racism, stating that their organisation of the march was far from unthinking, emphasising the amount of time put into liaising with local community groups in Chapeltown, as well as distributing over one thousand fliers locally outlining the aims of the march. They insisted that their publicity work was successful, due to the support they got from members of the public on the night of the march, and they stated that both marchers and observers understood and sympathised with the purpose of the march (WIRES 47, 1978:13).

The organisers also pointed out in their letter the reason why the selected route was so significant; reminding readers of the recent murders in the area, presumed to be further crimes of Sutcliffe, who at that time was still an unidentified serial killer. "We chose the Chapeltown route because of several brutal murders of women in the area over the last two years. This was understood by all the local people we talked to, informed of the march, gave leaflets to" (ibid). In the years leading up to the founding of RTN, the bodies of four of the women murdered by Sutcliffe, Wilma McCann in October 1975, Emily Jackson in January 1976, Irene Richardson in February 1977 and Jayne McDonald in June 1977, were all discovered in Chapeltown (Holloway, 1984). As Garthwaite reiterated:

"women had been murdered and left there [Chapeltown] by a White man; at that time we knew Sutcliffe was a White man so it wasn't about Black crime" (Al Garthwaite). 
A duplicate of the letter from RTN organisers, addressing the charge of racism, was also sent to 'Spare Rib' and was published in Issue 70, in May 1978.

\section{How accusations travel}

If the organisers hoped that their clarifying letter would put an end to the charges, they were wrong. Indeed the charge of racism is one that appears to have stuck to RTN and which has surfaced fairly frequently in articles on the Second Wave, the feminism of the late 1960s to the 1980s. In 1986, Bhavnani and Coulson wrote an article for 'Feminist Review, re-printed in a special twenty five year review edition in 2005, in which they assert that the racism of the UK Women's Liberation Movement can be clearly seen in the example of RTN. Their particular reference to RTN has since been much quoted. They described: "the failure of anti-rape campaigns to challenge racist stereotypes of the sexuality of black men", and criticised the RTN marches of the 1970s and 1980s:

Not only have these generally not taken up racism as an issue, nor seen how their campaigns against male violence are complicated in the context of racism, but by their actions they have affirmed racist ideas by marching through black areas and calling for greater policing (2005:88).

Several academics have made similar charges, often referencing the Bhavnani and Coulson article from 1986, but never citing which RTN march/es in particular they are referring to. For example, this statement from Grover and Soothill in 1996: 
This is an author pre-print of an article published in Women's Studies International Forum. The definitive publisher-authenticated version Mackay Finn (2014) 'Mapping The Routes: An exploration of charges of racism made against 1970s UK Reclaim the Night marches', Women's Studies International Forum, 44, pp. 46-54 is available online at: http://www.sciencedirect.com/science/article/pii/S0277539514000521

Although the bestial imagery of black male sexuality was at its height in the nineteenth century, it is an image which still exists. It is significant that the 'reclaim the night' marches in the mid to late 1970s focused on areas in which the communities had a high proportion of minority ethnic men.

These authors then refer readers to the Bhavnani and Coulson article (Grover \& Soothill, 1996:568).

A similar statement is made in a 1990 article by Cox, though there is no reference to any previous article, indeed there is no reference at all for the following claim:

The 'Reclaim the Night' marches in the late 1970s demanded, amongst other things, greater police protection for 'women' (read: white women). Many of these marches were routed through the hearts of black communities. Not only was this interpreted as an invitation to exert greater control over these areas, but it reinforced the association of Afro-Caribbean youth with crime. This played into racist notions of the 'coloured' male rapist and white female victim (Cox, 1990:239).

In 1991, Tang Nain repeated this accusation, again without any reference to examples or previous articles:

There have, however, been problems with 'reclaim the night' marches in Britain, for example, when some white feminists marched in areas of black concentration. This had the effect of suggesting a link between black people and violence and was justly criticised (Tang Nain, 1991:12). 


\section{Contextualising the charges}

Whether all such charges against RTN could be traced back to thirty women marching through Chapeltown in Leeds in 1977 is unknown. As mentioned earlier, the organisers explicitly refuted the specific charges made at the time. In their letters to 'WIRES' and 'Spare Rib' RTN organisers stated that they were well aware of the racist connotations that could be attached to a group carrying flaming torches marching through a community with a high percentage of BME residents. This was another reason organisers gave for focussing on awareness raising and advertising around Leeds and especially in the two areas chosen as assembly points for the routes of the march: Chapeltown and Hyde Park.

On the night of the march itself this awareness raising continued. The fliers which organisers printed and gave out to bystanders at their Leeds RTN march had only one simple statement: "we are walking for all women - all women should be free to walk down any street night or day without fear" (SR 66, 1978:23). Although the accusations against RTN also included the assertion that the march demanded increased policing, it will be recalled, as stated in the introduction to this article, that the official two themes of $\mathrm{RTN}$, from the original call out in July 1977, and in subsequent adverts, were nothing to do with increased policing, being only: "fight rape" and: "every woman has the right to walk alone at night without fear" (ibid). Most RTN organising groups around the country actually decided not to engage with the police at all, reflecting the characteristics of a movement, which at that time, was largely working outside the state (ibid). This was a point emphasised by McNeill, referring to the first London RTN in 1977: 
“God no, we didn't get police permission. I mean no, I mean that to us at the time would have been an anathema" (Sandra McNeill).

The concerns over policing at the time when RTN emerged in the UK were understandable. Britain in the late 1970s and 1980s was fraught with racial tensions and marked by explosive clashes between the police and marginalised urban communities (Beckett, 2010). Reflecting racist and inadequate housing and welfare policies, such communities were often made up of a high number of BME citizens and were areas: "defined by urban decay and official neglect" (Hernon, 2006:201). The imposition of stop and search powers, known colloquially as the 'sus laws' gave free reign to the police to accost, harass and question anyone they thought to be behaving suspiciously, a law which was used disproportionately in UK cities against young Black people, mainly men (McSmith, 2010; Hall et al, 1978). This discrimination did not stop with harassment, with the police being implicated in numerous cases of racist violence, some of it fatal.

Leeds in 1971 had actually seen the first, and to this date, the only, successful prosecution following a death in police custody. In 1969 the body of a beaten Nigerian man, David Oluwale was pulled from the River Aire, witnesses had reported seeing him running through the streets screaming, being chased and attacked by two police officers. The two officers, Ken Kitching and Geoff Ellerker, had waged a long period of sustained racist violence against Oluwale, the brutal facts of which emerged at their trial for manslaughter. Such incidents of racist discrimination at the hands of the police eventually resulted in violent resistance across England, for example in Bristol in the South West, in Toxteth in Liverpool in the North, and also in Brixton, London in the 'riots' of the Spring and Summer of 
This is an author pre-print of an article published in Women's Studies International Forum. The definitive publisher-authenticated version Mackay Finn (2014) 'Mapping The Routes: An exploration of charges of racism made against 1970s UK Reclaim the Night marches', Women's Studies International Forum, 44, pp. 46-54 is available online at: http://www.sciencedirect.com/science/article/pii/S0277539514000521

1981 (Hernon, 2006). The disturbances in Brixton were later the subject of the Scarman Report, published by the Government in November of that year and recommending urgent action on racial discrimination; although tellingly, refusing to accept the existence of institutional racism within the police or any other part of the state (Scarman, 1981).

Police harassment and biased stop and search exercises continued however, disproportionately affecting Black people, particularly young Black men; cases of assault and further tragic deaths in police custody also continued. In such a climate the police, for many people, especially Black people, were not seen as a source of protection, but as a threat. Many women, in particular Black women, but also poor or otherwise marginalised women, may therefore have had understandable reticence towards a women's movement or protest that they believed to be calling for increased policing. Unfortunately, concerns over racist policing are far from history, and remain key social justice issues today (Thiara \& Gill, 2010; Amina, 1989). Black males are still disproportionately represented in the statistics on deaths in police custody in the UK for example (Athwal, 2011; Jasper, 2011; Malik, 1995), and recent figures suggest that Black and Asian people in the UK, particularly young males, are still overwhelmingly the target of police stop and search exercises (Dodd, 2012). Men are by no means the only victims, with some of the most infamous cases of police brutality over the years resulting in the deaths of women, for example Cynthia Jarrett and Cherry Groce in London in 1985, and Joy Gardner also in London in 1993; their families are still awaiting justice (Fero, 1995).

\section{Race, Rape and Racism}


This is an author pre-print of an article published in Women's Studies International Forum. The definitive publisher-authenticated version Mackay Finn (2014) 'Mapping The Routes: An exploration of charges of racism made against 1970s UK Reclaim the Night marches', Women's Studies International Forum, 44, pp. 46-54 is available online at: http://www.sciencedirect.com/science/article/pii/S0277539514000521

The context of brutally racist policing in the UK at the time of RTN's emergence could possibly explain some of the suspicions around the march and its perceived aims. Another possible reason for those suspicions may lie in the historic racist and sexist links between rape and racism. This linkage was not a construct of feminists however, let alone those organising RTN in Leeds in 1977, and it dates back to at least the period of slavery in both the UK and the US (Bourke, 2007; Davis, 1982; Brownmiller, 1976). Bourke (2007) and Brownmiller (1976) for example, in their thorough histories of rape, highlight that in the US and the UK there has long been more frequent and more severe punishment for Black men accused of rape as compared to White males; particularly when the alleged victim was a White woman. Black women meanwhile, as Crenshaw (1991) argues, rarely saw justice, and were often constructed in US law as almost un-rapeable, being subject to both racist and patriarchal sexual stereotypes, regardless of the ethnicity of any alleged assailant. These stereotypes associated White women with passive purity in need of paternalistic protection from White males, Black women with animalistic, insatiable sexuality and Black men with sexual violence and predation. Early works such as the infamous American film The Birth Of A Nation directed by DW Griffiths (1915), clearly reflect such racist assumptions, suggesting that Black males are biological rapists due to their ethnicity.

Such racist and patriarchal stereotypes connecting sex, race and rape have arguably not lost their impact. For example, in Britain in late 2010, in a well publicised case concerning the grooming and prostitution of girls and young women in Derby in the Midlands region of England, certain elements of the media, and some politicians, chose to focus on the Asian ethnicity of the men charged, rather than the generic issue of male sexual violence against women, or the male demand for prostitution (Brooks, 2011; Reid, 2010). In 2013 similar racism was clear in commentary over a case involving the grooming 
This is an author pre-print of an article published in Women's Studies International Forum. The definitive publisher-authenticated version Mackay Finn (2014) 'Mapping The Routes: An exploration of charges of racism made against 1970s UK Reclaim the Night marches', Women's Studies International Forum, 44, pp. 46-54 is available online at: http://www.sciencedirect.com/science/article/pii/S0277539514000521

and prostitution of girls in Oxford, in the South of England, where the charged perpetrators were Asian and allegedly of Muslim faith (Pearson, 2013). Such racist coverage continues despite the fact that official reports show the majority of those charged with sexual offences against children are White men (CPS, 2013; Berlowitz et al, 2012).

These cases above highlight how easily issues of male violence against women can be hijacked by a racist media to fuel racism; while the all too real facts of sexual exploitation and abuse are sidelined in the process. This was no less the case in 1977 when RTN was founded in the UK. Therefore there were justifiable suspicions around the pioneering and evolving politicisation of the issue of male sexual violence at that time, in a racist context where Black communities had for a long time already been stereotyped as not only disproportionately affected by such crimes, but disproportionately the perpetrators of such crimes (Crenshaw, 1991). The perception of RTN may well have been influenced by these concerns. Perceptions of the protest may also have been influenced by more general critiques of Western feminism, and of the Second Wave in particular, as lacking in intersectional analysis (Crenshaw, 1989) and overlooking race and racism (hooks, 1986). These critiques were highlighted by Carby in her influential 1982 essay addressing White women, when she summarised: "Many black women had been alienated by the nonrecognition of their lives, experience, and herstories in the Women's Liberation Movement" (1982:211).

In the 1970s and 1980s debates around who the Women's Liberation Movement could speak for, and concerns over the universality of Sisterhood were key. Tensions around power relations between women, not only along the fractures of race, but also social class and sexuality for example, troubled the idea of a universal women's movement which 
This is an author pre-print of an article published in Women's Studies International Forum. The definitive publisher-authenticated version Mackay Finn (2014) 'Mapping The Routes: An exploration of charges of racism made against 1970s UK Reclaim the Night marches', Women's Studies International Forum, 44, pp. 46-54 is available online at: http://www.sciencedirect.com/science/article/pii/S0277539514000521

could act for all women. In turn, this troubled the possibility of a meaningful identity that could comfortably contain all women, in all their diversity. These tensions were present from the early days of the Second Wave (Rowland \& Klein, 1996). These tensions, including racism, were acknowledged and wrestled with in Consciousness Raising groups and at conferences throughout the UK as feminists tried to avoid and interrogate essentialism. This history reveals itself in published accounts as well as in letters and articles in periodicals of the time (Kanter et al, 1984; FAC, 1981; Freeman, 1975; Morgan, 1970). As Roseneil (1995) points out: "The vast majority of feminist theory has long been determinedly anti-essentialist, and even in the 1970s feminist activists paid considerable attention to differences within the category of 'woman' and to the problem of constructing a politicised identity as women" (Roseneil, 1995:142).

The evidence of debate on these issues in the movement of the 1970s when RTN first emerged however, does not mean that the power relationships between women, or prejudice between and amongst women, were all eradicated, solved or resolved positively. Clearly this is not the case, as these remain ongoing concerns for feminism as a movement, with racism and ethnocentrism still troubling notions of Sisterhood and solidarity (Kendall, 2013; Redfern \& Aune, 2013; Brison, 2011). As women are not a homogenous group, power relations between women remain a challenging source of possible obstruction within contemporary feminist activism. Women in all their diversity are obviously not immune to the exercise of power, or to practices of prejudice including racism; women are neither angels nor saints. As Withers (2012) highlights, it was, and still is, unrealistic to expect that the Women's Liberation Movement could operate in a vacuum unaffected by the vortex of social power relations it exists within. "Experiences of disempowerment in mixed groups also created unrealistic expectations that organising with women would be vastly different" (Withers, 2012:84). The persistence of racism for example, within a movement 
This is an author pre-print of an article published in Women's Studies International Forum. The definitive publisher-authenticated version Mackay Finn (2014) 'Mapping The Routes: An exploration of charges of racism made against 1970s UK Reclaim the Night marches', Women's Studies International Forum, 44, pp. 46-54 is available online at: http://www.sciencedirect.com/science/article/pii/S0277539514000521

aimed at overturning oppression is perhaps an example of what Verloo calls the 'interfering inequalities', which complicate and trouble the passage of all equality movements; feminism being no exception (2013).

When RTN first emerged in the UK it was therefore just one element of a wider Women's Liberation Movement which had already been justly critiqued for historic and ongoing racism and ethnocentrism. It is perhaps then unsurprising that RTN, as one highly visible and well publicised aspect of that movement, also became subject to these valid, and still pressing critiques. However, the specific charges being investigated here, which were made against the original RTN, rely on claims that the early marches called explicitly for increased policing and that they cynically targeted their protests in predominantly BME communities. I have endeavoured to show in this article that these particular charges are unfounded.

\section{The Rally and After-Party: Concluding remarks}

The accusations of racism made against the original RTN, within the academic texts cited in this article, have never referenced a particular RTN march, or particular publicity material from an original RTN march. I have found no evidence that the original marches called for increased policing, nor that they purposely targeted BME areas, nor that they made links between Black masculinity and the crime of rape. What the articles in periodicals of the time do suggest, is that women marched on RTN in 1977 because they felt that women were being blamed for male sexual violence, and they felt women were unfairly expected to curtail their freedom in order to evade that violence. My research with 
This is an author pre-print of an article published in Women's Studies International Forum. The definitive publisher-authenticated version Mackay Finn (2014) 'Mapping The Routes: An exploration of charges of racism made against 1970s UK Reclaim the Night marches', Women's Studies International Forum, 44, pp. 46-54 is available online at: http://www.sciencedirect.com/science/article/pii/S0277539514000521

organisers and participants of UK RTN marches past and present found strikingly similar motivations for marching on the protest today.

Recently, in the city of Bristol where I live and work, the start of the academic term in September 2013 was marked by two horrific sexual assaults on young people. Following one of these attacks on a young female student, the local police issued guidance to women to avoid walking home alone after dark, and reminded women that drinking alcohol makes them 'vulnerable' (Norris, 2013). The police issued no such guidance following the second attack, a multiple perpetrator sexual assault on a young man in his twenties, who was walking through the city centre in the early hours of the morning following a night out clubbing. It was just this sort of sexist, victim-blaming paternalism, and impractical police advised curfews, which first ignited the tradition of RTN marching in the UK over thirty years ago in 1977.

Founded in women's anger and resistance, the autonomous, women-only marches of the 1970s inspired a global movement. RTN was how people in India reacted to the gang rape and murder of a young student woman in Delhi in December 2012 for example, with tens of marches held in towns and cities, including Delhi and Mumbai, widely covered in local media such as: 'The Shillong Times', 'The Hindustan Times', and the 'Times of India' (O'Toole, 2013). This particular form of protest was also how people in Australia chose to react to the rape and murder of Jill Meagher, on her way home one night in Melbourne in September 2012; with thousands joining RTN marches in that city and beyond (Elgot, 2012). 
This is an author pre-print of an article published in Women's Studies International Forum. The definitive publisher-authenticated version Mackay Finn (2014) 'Mapping The Routes: An exploration of charges of racism made against 1970s UK Reclaim the Night marches', Women's Studies International Forum, 44, pp. 46-54 is available online at: http://www.sciencedirect.com/science/article/pii/S0277539514000521

This article has revisited charges of racism made against the original UK RTN marches, and explored some of the possible reasons why these concerns arose at that time. I have discussed the context of racist policing, which arguably contributed to a suspicion of a protest perceived to be primarily focussed on criminal justice remedies for rape and sexual violence. These issues of rape and sexual violence, addressed by the protest, were also highly charged invoking concerns around historic patriarchal and racist associations between rape and race. I have also highlighted that RTN was just part of a movement which had for a long time already been critiqued for racism and ethnocentrism. Being a high profile and nationally publicised street protest, it is unsurprising therefore that RTN also became subject to these same concerns and critiques.

In conclusion, since the 1970s the UK RTN marchers have protested all forms of male violence against women, at home, at work and on the streets. RTN was rooted in a still urgent claim for all women - the right to live free from the fear of male violence. The original marches were routed through the towns and cities in which the activists lived, and the women marchers loudly occupied those places where they so often felt isolated and vulnerable. The message and tactic appears to have resonated, as the legacy lives on in the hundreds of RTN marches still taking place today across the globe, and in all the women who take part. For all those marchers it is important to reclaim the history of RTN, and I have tried to do that here.

\section{References}


This is an author pre-print of an article published in Women's Studies International Forum. The definitive publisher-authenticated version Mackay Finn (2014) 'Mapping The Routes: An exploration of charges of racism made against 1970s UK Reclaim the Night marches', Women's Studies International Forum, 44, pp. 46-54 is available online at: http://www.sciencedirect.com/science/article/pii/S0277539514000521

Amina Mama (1989) The hidden struggle: statutory and voluntary sector responses to violence against black women in the home. London: London Race and Housing Research Unit.

Antubam Susuana (2013) 'London Student Women Reclaim the Night', NUS Connect. $30^{\text {th }}$ October. Available at: http://www.nusconnect.org.uk/news/article/womens/London-StudentWomen-Reclaim-the-Night-2013/ [Accessed 20 ${ }^{\text {th }}$ December 2013].

Aspden Kester (2008) The Hounding of David Oluwale. London: Vintage.

Athwal Harmit (2011) 'The Spotlight is Back on Black Deaths At the Hands of Police', Institute of Race Relations, Comment. $31^{\text {st }}$ August. Available at:

http://www.irr.org.uk/news/the-spotlight-is-back-on-black-deaths-at-the-hands-of-police/ [Accessed $7^{\text {th }}$ January 2014].

Beckett Andy (2010) When the Lights Went Out: Britain in the Seventies. London: Faber and Faber.

Berlowitz Sue et al (2012) 'I thought I was the only one. The only one in the world' The Office of the Children's Commissioner's Inquiry into Child Sexual Exploitation in Gangs and Groups'. Interim Report. London: OCC.

Bhavnani Kum-Kum and Coulson Margaret (2005) Transforming Socialist-Feminism: The Challenge of Racism, Feminist Review, No. 80, pp. 87-97. 
This is an author pre-print of an article published in Women's Studies International Forum. The definitive publisher-authenticated version Mackay Finn (2014) 'Mapping The Routes: An exploration of charges of racism made against 1970s UK Reclaim the Night marches', Women's Studies International Forum, 44, pp. 46-54 is available online at: http://www.sciencedirect.com/science/article/pii/S0277539514000521

Bouchier David (1983) The feminist challenge: the movement for women's liberation in Britain and the USA. London: Macmillan.

Bourke Joanna (2007) Rape: A History from 1860 to the present. London: Virago.

Brison Susan (2011) 'An Open Letter from Black Women to SlutWalk Organisers', Huffington Post, $27^{\text {th }}$ September.

Brooks Libby (2011) 'Grooming and our ignoble tradition of racialising crime', The Guardian, $7^{\text {th }}$ January.

Brown Jennifer, Horvath Miranda, Kelly Liz \& Westmarland Nicole (2010) Has Anything Changed? Results of a comparative study (1977-2010) on opinions on rape. Government Equalities Office.

Brownmiller Susan (1976) Against Our Will. London: Penguin.

Budgeon Shelley (2011) Third Wave Feminism and the Politics of Gender in Late Modernity. Basingstoke: Palgrave Macmillan.

Carby Hazel V. (1982) 'White woman listen! Black feminism and the boundaries of sisterhood' in Centre for Contemporary Cultural Studies (eds.) The Empire Strikes Back: Race and Racism in 70s Britain. London: Hutchinson \& Co, pp. 211-235. 
This is an author pre-print of an article published in Women's Studies International Forum. The definitive publisher-authenticated version Mackay Finn (2014) 'Mapping The Routes: An exploration of charges of racism made against 1970s UK Reclaim the Night marches', Women's Studies International Forum, 44, pp. 46-54 is available online at: http://www.sciencedirect.com/science/article/pii/S0277539514000521

Chan Beatrice (2004) Reclaim The Night, paper presented at Social Movements in Action conference, University of New South Wales.

Cox Cherise (1990) 'Anything Less Is Not Feminism: Racial Difference And The WMWM', Law and Critique, 1(2), pp. 237-248.

CPS Crown Prosecution Service (2013) ‘Violence against Women and Girls Crime Report 2012-2013'. London: CPS Public Accountability and Inclusion Directorate.

Crenshaw Kimberle (1991) 'Mapping the Margins: Intersectionality, Identity Politics, and Violence against Women of Colour', Stanford Law Review, 43 (6), pp. 1241-1299.

Crenshaw Kimberle (1989) ‘Demarginalising the Intersection of Race and Sex: A Black Feminist Critique of Antidiscrimination Doctrine, Feminist Theory, and Antiracist Politics', University of Chicago Legal Forum, 14, pp. 538-554.

Davis Angela Y. (1982) Women, Race and Class. London: Women's Press.

Dean Jonathan (2010) Rethinking Contemporary Feminist Politics. Basingstoke: Palgrave Macmillan.

Dodd Vikram (2012) 'Police up to 28 times more likely to stop and search black people study', The Guardian, $12^{\text {th }}$ June. 
This is an author pre-print of an article published in Women's Studies International Forum. The definitive publisher-authenticated version Mackay Finn (2014) 'Mapping The Routes: An exploration of charges of racism made against 1970s UK Reclaim the Night marches', Women's Studies International Forum, 44, pp. 46-54 is available online at: http://www.sciencedirect.com/science/article/pii/S0277539514000521

Elgot Jessica (2012) 'Jill Meagher: Death Sparks Melbourne 'Reclaim The Night’ Protest Over Women's Safety', The Huffington Post UK, $28^{\text {th }}$ September.

Erickson Bailee (2010) 'Every Woman Needs Courage: Feminist Periodicals in 1970s West Germany', Preteritus: A Graduate History Journal, Vol: 2.

FAC: Feminist Anthology Collective (ed.) (1981) No Turning Back: Writings from the women's liberation movement, 1975-1980. London: Women's Press.

Fero Ken (Dir.) (1995) Justice Denied. Migrant Media. Available at: http://vimeo.com/70408219 [Accessed 20 $0^{\text {th }}$ December 2013].

Freeman Jo (1975) The Politics of Women's Liberation. New York: David McKay Company Inc.

G Helen (2012) 'Update: Trans Inclusion and Reclaim the Night London', The F Word, $24^{\text {th }}$ October. Available at: http://www.thefword.org.uk/blog/2012/10/update_trans_inclusion_rtn [Accessed 25 $5^{\text {th }}$ October, 2012].

Gangoli Geetanjali (2007) Indian Feminisms: Campaigns against violence and multiple patriarchies. Surrey: Ashgate.

Grover Chris and Soothill Keith (1996) 'Ethnicity, the search for rapists and the press', Ethnic and Racial Studies, 19(3), pp. 567-584. 
This is an author pre-print of an article published in Women's Studies International Forum. The definitive publisher-authenticated version Mackay Finn (2014) 'Mapping The Routes: An exploration of charges of racism made against 1970s UK Reclaim the Night marches', Women's Studies International Forum, 44, pp. 46-54 is available online at: http://www.sciencedirect.com/science/article/pii/S0277539514000521

Hall Stuart, Critcher Chas, Jefferson Tony \& Roberts Brian (1978) Policing the Crisis:

Mugging, the State and Law and Order. London: Macmillan.

Hernon lan (2006) Riot!: Civil Insurrection from Peterloo to the Present Day. London: Pluto Press.

Holloway Wendy (1984) '"I Just Wanted to Kill a Woman". Why? The Ripper and Male Sexuality' in Kanter Hannah et al (eds.) Sweeping Statements. London: The Women's Press, pp.26 -46 .

Jasper Lee (2011) 'Deaths in police custody cut deep in the psyche of black Britons', The Guardian, $15^{\text {th }}$ December.

Jeffreys Sheila (2012) 'Let us be free to debate transgenderism without being accused of "hate speech", The Guardian, $29^{\text {th }}$ May. Available at:

http://www.theguardian.com/commentisfree/2012/may/29/transgenderism-hate-speech [Accessed $1^{\text {st }}$ June, 2012].

Kanter Hannah et al (eds.) (1983) Sweeping statements: writings from the women's liberation movement, 1981-1983. London: Women's Press.

Kaveney Ros (2012) 'Radical Feminists are acting like a cult', The Guardian, $25^{\text {th }}$ May. Available at: http://www.theguardian.com/commentisfree/2012/may/25/radical-feminismtrans-radfem2012 [Accessed $27^{\text {th }}$ May, 2012]. 
This is an author pre-print of an article published in Women's Studies International Forum. The definitive publisher-authenticated version Mackay Finn (2014) 'Mapping The Routes: An exploration of charges of racism made against 1970s UK Reclaim the Night marches', Women's Studies International Forum, 44, pp. 46-54 is available online at: http://www.sciencedirect.com/science/article/pii/S0277539514000521

Kendall Mikki (2013) ‘\#SolidaritylsForWhiteWomen: Women of colour’s issue with digital feminism', The Guardian, $14^{\text {th }}$ August. Available at:

http://www.theguardian.com/commentisfree/2013/aug/14/solidarityisforwhitewomenhashtag-feminism [Accessed $15^{\text {th }}$ August, 2013].

Long Julia (2012) Anti-Porn: The Resurgence of Anti-Pornography Feminism. London: Zed Press.

LRCC: London Rape Crisis Centre (1984) Sexual Violence. London: The Women's Press.

McSmith Andy (2010) No Such Thing As Society: A History of Britain in the 1980s. London: Constable.

Malik Kenan (1995) 'Too many killings to ignore', The Independent, $17^{\text {th }}$ December [Online].

Morgan Robin (1970) Sisterhood is Powerful. New York: Vintage Books.

Norris Sian (2013) 'Safety advice and victim blaming - an open letter to my local police force', Sian and Crooked Rib, $17^{\text {th }}$ October. Available at: http://sianandcrookedrib.blogspot.co.uk/2013/10/safety-advice-and-victim-blamingopen.html [Accessed 19 October 2013].

O'Toole Emer (2013) ‘Delhi gang-rape: look westward in disgust', The Guardian, $1^{\text {st }}$ January. 
This is an author pre-print of an article published in Women's Studies International Forum. The definitive publisher-authenticated version Mackay Finn (2014) 'Mapping The Routes: An exploration of charges of racism made against 1970s UK Reclaim the Night marches', Women's Studies International Forum, 44, pp. 46-54 is available online at: http://www.sciencedirect.com/science/article/pii/S0277539514000521

Redfern Catherine \& Aune Kristin (2013) Reclaiming The F Word: Feminism Today (revised edition). London: Zed Books.

Rees Jeska (2007) All the rage: revolutionary feminism in England, 1977- 1983. Unpublished PhD thesis. University of Western Australia.

Reid Sue (2010) 'Asian gangs, schoolgirls and a sinister taboo: As nine men are jailed for grooming up to 100 for sex, the disturbing new trend few dare talk about', Daily Mail, $27^{\text {th }}$ November.

Roseneil Sasha (1995) Disarming Patriarchy: Feminism and Political Action at Greenham. Buckingham: Open University Press.

Rowland Robyn \& Klein Renate D. (1991) 'Introduction', in Gunew Sneja (ed) A Reader in Feminist Knowledge. London: Routledge, pp. 305-307.

Russell Diana E. H. and Van de Ven Nicole (1976) The Proceedings of the International Tribunal on Crimes Against Women. California: Les Femmes.

Scarman Leslie George (1981) The Brixton disorders 10-12 April 1981: Report of an inquiry. London: HMSO.

SR - Spare Rib

May 1977, Issue 58.

August 1977, Issue 61. 
This is an author pre-print of an article published in Women's Studies International Forum. The definitive publisher-authenticated version Mackay Finn (2014) 'Mapping The Routes: An exploration of charges of racism made against 1970s UK Reclaim the Night marches', Women's Studies International Forum, 44, pp. 46-54 is available online at: http://www.sciencedirect.com/science/article/pii/S0277539514000521

September 1977, Issue 62.

November 1977, Issue 64.

January 1978, Issue 66.

May 1978, Issue 70.

Tang Nain Gemma (1991) ‘Black Women, Sexism and Racism: Black or Antiracist Feminism?', Feminist Review, 37 (Spring), pp. 1-22.

TBTN - Take Back The Night, online archive, launched 2001

http://www.takebackthenight.org/history.html

[Accessed $7^{\text {th }}$ December 2010]

Thiara Ravi K. \& Gill Aisha K. (eds.) (2010) Violence Against Women in South Asian

Communities: Issues for Policy and Practice. London: Jessica Kingsley.

Toynbee Polly (1977) 'Reclaim the night', The Guardian, $14^{\text {th }}$ November 1977, in Cohrane Kira (ed.) (2010) Women of the Revolution: Forty years of feminism. London: Guardian Books, pp. 49-55.

Verloo Mieke (2013) 'Intersectional Politics and Policies: Reflections on Current Practices and Debates', Signs, 38 (4), (forthcoming) (Advance copy from author).

\section{WIRES -}

July 1977, Issue 36 .

September 1977, Issue 38. 
This is an author pre-print of an article published in Women's Studies International Forum. The definitive publisher-authenticated version Mackay Finn (2014) 'Mapping The Routes: An exploration of charges of racism made against 1970s UK Reclaim the Night marches', Women's Studies International Forum, 44, pp. 46-54 is available online at: http://www.sciencedirect.com/science/article/pii/S0277539514000521

October 1977, Issue 40.

November 1977, Issue 41.

December 1977, Issue 42.

January 1978, Issue 43.

March 1978, Issue 47.

Withers Deborah M. (2012) 'Women's liberation, relationships and the 'vicinity of trauma",

Oral History, (Spring), pp. 79-88.

WORDCOUNT $=8655$ including references 